\title{
Distinguishing Heterodera filipjevi and $H$. avenae Using Polymerase Chain Reaction-Restriction Fragment Length Polymorphism and Cyst Morphology
}

\author{
Guiping Yan and Richard W. Smiley
}

Oregon State University, Columbia Basin Agricultural Research Center, P.O. Box 370, Pendleton 97801.

Accepted for publication 1 November 2009.

\begin{abstract}
Yan, G. P., and Smiley, R. W. 2010. Distinguishing Heterodera filipjevi and $H$. avenae using polymerase chain reaction-restriction fragment length polymorphism and cyst morphology. Phytopathology 100:216-224.

The cereal cyst nematodes Heterodera filipjevi and $H$. avenae impede wheat production in the Pacific Northwest (PNW). Accurate identification of cyst nematode species and awareness of high population density in affected fields are essential for designing effective control measures. Morphological methods for differentiating these species are laborious. These species were differentiated using polymerase chain reaction restriction fragment length polymorphism (PCR-RFLP) of internal tran-

validated by inspecting underbridge structures of cyst vulval cones. Grid soil sampling of an Oregon field infested by both species revealed that $H$. filipjevi was present at most of the infested grid sites but mixtures of $H$. avenae and $H$. filipjevi also occurred. These procedures also detected and differentiated $H$. filipjevi and $H$. avenae in soil samples from nearby fields in Oregon and $H$. avenae in samples from Idaho and Washington. Intraspecific polymorphism was not observed within $H$. filipjevi or PNW $H$. avenae populations based on the ITS-rDNA. However, intraspecific variation was observed between $H$. avenae populations occurring in the PNW and France. Methods described here will improve detection and identification efficiencies for cereal cyst nematodes in wheat fields.
\end{abstract} scribed spacer (ITS)-ribosomal (r)DNA with up to six restriction endonucleases (TaqI, HinfI, PstI, HaeIII, RsaI, and AluI). The method was

The genus Heterodera includes 12 species that affect roots of cereals and grasses. These species of cereal cyst nematodes $(\mathrm{CCN})$ are designated as the Heterodera avenae group (8). Three species ( $H$. avenae, $H$. filipjevi, and $H$. latipons) are among the most economically important cyst nematode pests to cultivated cereals $(14,22)$. H. avenae is widely distributed in temperate wheat-producing regions throughout the world $(16,17,22,27) . H$. filipjevi is found in eastern and northern Europe, central and west Asia, the Middle East, the Indian subcontinent, and North America $(23,27,29)$. H. latipons occurs mainly in the Mediterranean region but also in Asia and Europe $(1,27)$. Two other species in the $H$. avenae group, $H$. bifenestra and $H$. hordecalis, are also associated with wheat elsewhere in the world but are less prevalent (27).

Four species in the $H$. avenae group (H. avenae, $H$. filipjevi, $H$. mani, and $H$. ustinovi $[=H$. iri] $)$ have been reported in the United States but only $H$. avenae and $H$. filipjevi are parasitic to wheat. $H$. avenae was first discovered in Oregon during 1974 (11) and now occurs in many cereal-producing regions of the Pacific Northwest (PNW), including the states of Idaho, Oregon, and Washington $(5-7,25,26,28)$. High populations of $H$. avenae in commercial fields have reduced winter wheat yields as much as $50 \%$ and occasionally destroyed recropped spring wheat in Union County, Oregon $(25,26,28)$. H. filipjevi was first reported in the United States following discovery during 2008 in a winter wheat field near Imbler in Union County $(29,42)$. Large patches of stunted plants with up to $90 \%$ plant mortality occurred in the field

Corresponding author: G. P. Yan; E-mail address: guiping.yan@ oregonstate.edu

doi:10.1094/PHYTO-100-3-0216

(c) 2010 The American Phytopathological Society
Additional keywords: $\mathrm{CCN}$, H. latipons, restriction pattern. but the distribution pattern of $H$. filipjevi within that field and the possible occurrence in surrounding areas of Union County and other locations in the PNW were unknown.

There are no registered chemicals or biological controls that are effective for reducing populations of these cyst nematodes on wheat in the United States (25). Rotation of wheat with any broadleaf crop or with weed-free summer fallow improves wheat yields compared with annual wheat (26) but crop rotation does not allow sufficiently intensive wheat production to maintain farm profitability. The use of wheat cultivars that are both resistant and tolerant offers the most effective, economic, and environmentally friendly option to control damage from these nematodes $(25,27)$. However, individual wheat cultivars may differ in their ability to resist these nematodes; a cultivar exhibiting resistance to $H$. avenae is not necessarily resistant to $H$. filipjevi, and vice versa (15). Therefore, optimal management requires that the nematode species present in each field or region be accurately identified.

$H$. filipjevi is closely related to $H$. avenae and only minor morphological differences can differentiate them from each other (8). Distinction between these species, based on morphology, is time consuming and requires great skill and training by the observer. Polymerase chain reaction-restriction fragment length polymorphism (PCR-RFLP) based on the internal transcribed spacer (ITS) region of the ribosomal (r)DNA repeat unit has provided a reliable tool for quick and precise identification of cyst nematode species and subspecies $(1,2,12,23,29,32,33)$. The rDNA contains two ITS regions (ITS1 and ITS2) and the 5.8S gene located between the $18 \mathrm{~S}$ and $28 \mathrm{~S}$ genes. The ITS1 and ITS2 regions were thought to be more variable $(3,10)$ and were found to be useful for discriminating between species of the $H$. avenae group $(2,23)$. Comparative analysis of PCR-RFLP profiles and sequences of the ITS-rDNA of unknown nematode species with 
those of control species and known species published or deposited in GenBank facilitates rapid identification of most species of cyst nematodes (4,20,31-35). The information from molecular tests could strengthen microscopic identification based on the analysis of differences in morphology (23). Likewise, morphological identification is also needed to support the identification from molecular tests (8). Genetic differences between species inferred from molecular tests corresponded generally with divergence of specific morphological characters in the graminaceous cyst nematode complex $(23,33)$.

The objectives of this study were to (i) investigate population densities and distribution of $H$. filipjevi and $H$. avenae collected from an infested wheat field in the PNW; (ii) distinguish the two Heterodera spp. by PCR-RFLP restriction patterns, sequences of the ITS-rDNA, and cyst morphological characters; and (iii) examine possible intraspecific variation within $H$. avenae or $H$. filipjevi populations based on the ITS region of rDNA.

\section{MATERIALS AND METHODS}

Sample collection and nematode preparation. DNA standards of $H$. avenae (IB), $H$. filipjevi (E84 and E88), H. latipons (E99, E123, and E156), and H. schachtii (Hs) were acquired from cooperators in France and used as controls (Table 1). Each purified DNA was obtained from three gravid cysts (23). Isolates of $H$. avenae (Davis) and H. filipjevi (Imbler-A), verified in our previous experiments $(28,29,41)$, were also included as controls in this study (Table 1).

Grid soil sampling was conducted in the same Imbler (Union County, OR) field where H. filipjevi was first reported (29). A grid of $30 \mathrm{~m}$ was used to examine the uniformity of $H$. filipjevi distribution. In total, 50 soil samples (Fig. 1) were collected on 17 April 2008. Each sample consisted of 10 to 15 cores $(2.5 \mathrm{~cm}$ in diameter by $30 \mathrm{~cm}$ deep) within a $1-\mathrm{m}$ radius. Soil $(3 \mathrm{~kg})$ was collected in each sampling site and samples were stored at $4{ }^{\circ} \mathrm{C}$.

TABLE 1. Populations of Heterodera spp. used as controls in this study

\begin{tabular}{|c|c|c|c|c|}
\hline Species & Isolate code & Origin & Source $^{\mathrm{a}}$ & Reference \\
\hline Heterodera avenae & IB & Argentan, France & R. Rivoal & 23 \\
\hline H. avenae & Davis & Oregon, United States & R. W. Smiley & 28 \\
\hline H. filipjevi & E88 & Pushkin, Russia & R. Rivoal & 23 \\
\hline H. filipjevi & E84 & India & R. Rivoal & 1 \\
\hline H. filipjevi & Imbler-A & Oregon, United States & G. P. Yan & 29 \\
\hline H. latipons & E99 & Aimargues, France & R. Rivoal & 23 \\
\hline H. latipons & E123 & Tel Hadya, Syria & R. Rivoal & 23 \\
\hline H. latipons & E156 & Homs, Syria & R. Rivoal & 1,23 \\
\hline H. schachtii & Hs & Laon, France & R. Rivoal & 23 \\
\hline
\end{tabular}

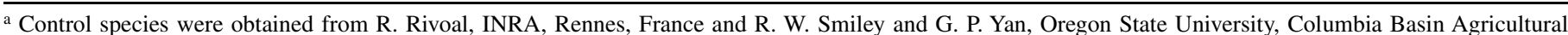
Research Center, Pendleton.

\begin{tabular}{|c|c|c|c|c|c|c|c|}
\hline $\begin{array}{c}\# 1 \\
0 \mathrm{CCN}\end{array}$ & $\begin{array}{c}\# 2^{a, b} \\
493 \\
\mathrm{Hf}+\mathrm{Ha}\end{array}$ & & & & $30 \mathrm{~m}$ & & \\
\hline $\begin{array}{c}\# 3 \\
0 \mathrm{CCN}\end{array}$ & $\begin{array}{c}\# 4 \\
0 \mathrm{CCN}\end{array}$ & $\begin{array}{c}\# 5 \\
0 \mathrm{CCN}\end{array}$ & $\begin{array}{c}\# 6^{a} \\
138 \\
\mathrm{Hf}+\mathrm{Ha}\end{array}$ & $\begin{array}{l}7^{\mathrm{a}} \\
64 \\
\mathrm{Hf}\end{array}$ & $\begin{array}{c}\# 8 \\
0 \mathrm{CCN}\end{array}$ & $\begin{array}{c}\# 9 \\
0 \mathrm{CCN}\end{array}$ & $\begin{array}{c}\# 10^{a, b} \\
1044 \\
\mathrm{Hf} \\
\end{array}$ \\
\hline $\begin{array}{c}\# 11 \\
0 \mathrm{CCN}\end{array}$ & $\begin{array}{c}\# 12^{\mathrm{a}} \\
65 \\
\mathrm{Hf}\end{array}$ & $\begin{array}{c}\# 13 \\
0 \mathrm{CCN}\end{array}$ & $\begin{array}{c}\# 14^{a, b} \\
611 \\
\mathrm{Hf}\end{array}$ & $\begin{array}{c}\# 15^{a} \\
68 \\
H f\end{array}$ & $\begin{array}{c}\# 16 \\
0 \mathrm{CCN}\end{array}$ & $\begin{array}{c}\# 17^{a} \\
151 \\
\mathrm{Hf}\end{array}$ & $\begin{array}{c}\# 18 \\
0 \mathrm{CCN}\end{array}$ \\
\hline $\begin{array}{c}\# 19 \\
0 \mathrm{CCN}\end{array}$ & $\begin{array}{c}\# 20 \\
0 \mathrm{CCN}\end{array}$ & $\begin{array}{c}\# 21 \\
0 \mathrm{CCN}\end{array}$ & $\begin{array}{c}\# 22 \\
0 \mathrm{CCN}\end{array}$ & $\begin{array}{c}\# 23^{a, b} \\
2446 \\
\mathrm{Hf} \\
\end{array}$ & $\begin{array}{c}\# 24 \\
0 \mathrm{CCN}\end{array}$ & $\begin{array}{c}\# 25 \\
0 \mathrm{CCN}\end{array}$ & $\begin{array}{c}\# 26^{a, b} \\
537 \\
\text { Hf } \\
\end{array}$ \\
\hline $\begin{array}{c}\# 27 \\
0 \mathrm{CCN}\end{array}$ & $\begin{array}{c}\# 28^{a} \\
63 \\
H f\end{array}$ & $\begin{array}{c}\# 29 \\
0 \mathrm{CCN}\end{array}$ & $\begin{array}{c}\# 30 \\
0 \mathrm{CCN}\end{array}$ & $\begin{array}{c}\# 31 \\
0 \mathrm{CCN}\end{array}$ & $\begin{array}{c}\# 32 \\
0 \mathrm{CCN}\end{array}$ & $\begin{array}{c}\# 33^{a} \\
104 \\
\mathrm{Hf}+\mathrm{Ha}\end{array}$ & $\begin{array}{c}\# 34^{a} \\
80 \\
H f\end{array}$ \\
\hline $\begin{array}{c}\# 35 \\
0 \mathrm{CCN}\end{array}$ & $\begin{array}{c}\# 36 \\
0 \mathrm{CCN}\end{array}$ & $\begin{array}{c}\# 37 \\
0 \mathrm{CCN}\end{array}$ & $\begin{array}{c}\# 38 \\
0 \mathrm{CCN}\end{array}$ & $\begin{array}{c}\# 39 a, b \\
955 \\
\mathrm{Hf} \\
\end{array}$ & $\begin{array}{c}\# 40 \\
0 \mathrm{CCN}\end{array}$ & $\begin{array}{c}\# 41 \\
0 \mathrm{CCN}\end{array}$ & $\begin{array}{c}\# 42^{a, b} \\
1110 \\
\mathrm{Hf} \\
\end{array}$ \\
\hline $\begin{array}{c}\# 43 \\
0 \mathrm{CCN}\end{array}$ & $\begin{array}{c}\# 44 \\
0 \mathrm{CCN}\end{array}$ & $\begin{array}{c}\# 45 \\
0 \mathrm{CCN}\end{array}$ & $\begin{array}{c}\# 46 \\
0 \mathrm{CCN}\end{array}$ & $\begin{array}{c}\# 47 \\
0 \mathrm{CCN}\end{array}$ & $\begin{array}{c}\# 48 \\
0 \mathrm{CCN}\end{array}$ & $\begin{array}{c}\# 49 \\
0 \mathrm{CCN}\end{array}$ & $\begin{array}{c}\# 50 \\
0 \mathrm{CCN}\end{array}$ \\
\hline
\end{tabular}

Fig. 1. Cereal cyst nematodes (CCNs) at 50 sampling sites within a field near Imbler, OR. Sampling was performed at 30-by-30-m grid intervals. Information shown for each sampling site includes the grid number $(\#)$, the number of $\mathrm{CCN}$ juveniles in $1 \mathrm{~kg}$ of soil extracted by the Whitehead tray method, and species $(\mathrm{Hf}=$ Heterodera filipjevi and $\mathrm{Ha}=H$. avenae) determined by polymerase chain reaction restriction fragment length polymorphism (a) and confirmed by underbridge structure in cyst vulval cones (b). The previous crop in this field was winter wheat cv. Chukar, and the sampling date was 17 April 2008. 
Cysts were extracted from soil by the routine sieving-decanting method. Extracted cysts retained on the $250-\mu \mathrm{m}$-pore sieve were hand picked with a dissecting needle under a stereomicroscope and stored at $4{ }^{\circ} \mathrm{C}$ for molecular and morphological identification. Vermiform juveniles were also extracted from soil using the Whitehead tray method (38). Second-stage juveniles of cyst nematodes in the extracted suspensions were identified and quantified on a nematode counting slide under a microscope and converted to the number per kilogram of soil.

Twenty other soil samples were collected from wheat fields or fields with recent wheat rotation thought to be infested with CCNs. These locations included farms near Union, Imbler, and Island City, OR; St. Anthony, ID; and Palouse, WA (Table 2). Samples were 10 to $300 \mathrm{~kg}$ and were collected using 10 to 50 shovel slices ( $10 \mathrm{~cm}$ wide by $15 \mathrm{~cm}$ deep) taken from areas within patches of stunted wheat plants, or from cultivated soil in areas of fields where farmers had previously observed stunted or uneven wheat growth. Approximately 1-kg subsamples were sent to Western Laboratories (Parma, ID) for nematode microscopic identification and quantification at the genus level. The numbers of Heterodera spp. eggs and juveniles in $1 \mathrm{~kg}$ of soil were reported as population density. Cysts extracted from the remaining soil samples, using the technique described above, were used for molecular and morphological examination.

DNA extraction from cyst nematodes. Three methods were used for total genomic DNA extraction. For samples with gravid cysts, three to five cysts were used per DNA extraction. The cysts were cut open and the eggs and juveniles crushed between two glass slides under a stereomicroscope. The nematode suspension was then pipetted and used to isolate DNA using either a commercial kit (FastDNA Kit; Bio 101, La Jolla, CA) according to the protocol recommended by the manufacturer (method 1) or the procedure described by Rivoal et al. (23) (method 2). For soil samples with empty cysts, juveniles were extracted from soils by the Whitehead tray method. Second-stage juveniles of cyst nematodes were hand picked using a dental pick from the mix of nematode suspension and used for DNA extraction. $\approx 20$ juveniles were picked per DNA extraction, placed in $20 \mu \mathrm{l}$ of sterilized nanopure water on a concave glass slide, and cut into two pieces under a stereomicroscope. DNA was extracted using the protocol described by Waeyenberge et al. (37), with some modifications. Suspension $(10 \mu \mathrm{l})$ containing the majority of nematode pieces was transferred into a $0.2-\mathrm{ml}$ sterile Eppendorf tube with $8 \mu \mathrm{l}$ of lysis buffer $(500 \mathrm{mM} \mathrm{KCl}, 100 \mathrm{mM}$ Tris- $\mathrm{HCl}$ [PH 8.3], $15 \mathrm{mM} \mathrm{MgCl}, 10 \mathrm{mM}$ dithiothreitol, $4.5 \%$ Tween 20, and $0.1 \%$ gelatin). The tube was frozen at $-20^{\circ} \mathrm{C}$ for at least $20 \mathrm{~min}$ and thawed; then, $2 \mu \mathrm{l}$ of proteinase $\mathrm{K}(600 \mu \mathrm{g} / \mathrm{ml})$ was added. The tubes were incubated at $65^{\circ} \mathrm{C}$ for $1 \mathrm{~h}$ and then at $95^{\circ} \mathrm{C}$ for $10 \mathrm{~min}$ to inactivate the proteinase $\mathrm{K}$. The nematode lysis mix was centrifuged at $16,000 \times g$ for $2 \mathrm{~min}$ and the supernatant was transferred to a clean tube and stored at $-20^{\circ} \mathrm{C}$ for PCR amplification. DNA extractions were conducted three times for each sample.

PCR amplification of ITS-rDNA. PCR reactions of $20 \mu \mathrm{l}$ contained $3 \mu$ of the DNA template, $1 \times$ PCR buffer with $1.5 \mathrm{mM}$ $\mathrm{MgCl}_{2}, 0.2 \mathrm{mM}$ dNTPs, $0.5 \mu \mathrm{M}$ each primer, $0.5 \mathrm{mM} \mathrm{MgCl}_{2}$, and 1.25 units of Taq polymerase (Roche, Mannheim, Germany). Primers 18S (5'-TTGATTACGTCCCTGCCCTTT-3') and 26S (5'-TTTCACTCGCCGTTACTAAGG-3'), as described by Vrain et al. (36), were used to amplify the ITS region of rDNA. PCR amplification was performed in a MyCycler Thermal Cycler (BioRad, Richmond, CA) as follows: $94^{\circ} \mathrm{C}$ for $2 \mathrm{~min}$; followed by 40 cycles of $94^{\circ} \mathrm{C}$ for $1 \mathrm{~min}, 60^{\circ} \mathrm{C}$ for $50 \mathrm{~s}$, and $72^{\circ} \mathrm{C}$ for $1 \mathrm{~min}$; with a final extension at $72^{\circ} \mathrm{C}$ for $7 \mathrm{~min}$. After PCR amplification, $5 \mu \mathrm{l}$ of each PCR product mixed with $1 \mu$ of $6 \times$ loading buffer (bromophenol blue in sucrose or Cresol Red in glycerol) were examined in a $1 \%$ standard agarose gel stained with ethidium bromide $(0.1 \mu \mathrm{g} / \mathrm{ml})$. The remaining PCR product was stored at $-20^{\circ} \mathrm{C}$.

RFLP analysis. Seven restriction endonucleases (TaqI, HinfI, PstI, HaeIII, RsaI, AluI, and CfoI) (Roche) were used. Digestions were carried out in $15-\mu l$ reaction mixtures containing 2 units of the enzyme, $1 \times$ enzyme buffer, and $10 \mu \mathrm{l}$ of the PCR product at optimum incubation conditions as recommended by the manufacturer for each enzyme. The DNA fragments were separated in a $1.8 \%$ standard agarose gel in $0.5 \times$ TBE buffer $(45 \mathrm{mM}$ Tris base, $45 \mathrm{mM}$ boric acid, and $1 \mathrm{mM}$ EDTA). The length of fragments was estimated by a 100-bp DNA ladder (Roche). The band pattern was photographed under UV light using a Polaroid digital camera and analyzed by the program of Polaroid PhotoMAX Pro (Polaroid, Bedford, MA). The species of Heterodera was determined by comparing the restriction pattern with those of the control species. The digestions of PCR products were performed three times for each soil sample.

TABLE 2. Soil samples from different locations in the Pacific Northwest and population densities of cyst nematodes (CNs) and species identity determined by polymerase chain reaction restriction fragment length polymorphism (PCR-RFLP) and underbridge structure in cyst vulval cones

\begin{tabular}{|c|c|c|c|c|c|c|c|}
\hline Soil name & Location & Sampling date & Previous crop & $\mathrm{CN}$ density ${ }^{\mathrm{a}}$ & PCR-RFLP ${ }^{b}$ & Underbridge $^{\mathrm{c}}$ & Species \\
\hline $\mathrm{Cu}-1$ & Union, OR & March 2005 & Wheat & 202 & $\mathrm{P}$ & N/A & Heterodera avenae \\
\hline Da-1 & Union, OR & March 2005 & Wheat & 2,160 & $\mathrm{P}$ & $\mathrm{U}$ & H. avenae \\
\hline Wa-1 & Union, OR & March 2005 & Wheat & 1,279 & $\mathrm{P}$ & $\mathrm{U}$ & H. avenae \\
\hline B-1 & Imbler, OR & April 2007 & Wheat & 2,946 & $\mathrm{P}$ & $\mathrm{U}$ & H. filipjevi \\
\hline C-1 & Imbler, OR & April 2007 & Wheat & 2,034 & $\mathrm{P}$ & $\mathrm{U}$ & H. filipjevi \\
\hline R-P6 & Imbler, OR & April 2008 & Wheat & 290 & $\mathrm{P}$ & $\mathrm{U}$ & H. filipjevi \\
\hline R-26 & Imbler, OR & May 2008 & Wheat & 120 & $\mathrm{P}$ & N/A & H. filipjevi \\
\hline $\mathrm{J}-1$ & Imbler, OR & May 2008 & Wheat & 400 & $\mathrm{P}$ & N/A & H. avenae \\
\hline $\mathrm{J}-2$ & Imbler, OR & May 2008 & Wheat & 420 & $\mathrm{P}$ & $\mathrm{U}$ & H. avenae \\
\hline U-1 & Imbler, OR & May 2008 & Wheat & 320 & $\mathrm{P}$ & $\mathrm{U}$ & H. avenae \\
\hline N-1 & Imbler, OR & May 2008 & Wheat & 40 & $\mathrm{P}$ & N/A & H. avenae \\
\hline W-1 & Island City, OR & October 2008 & Wheat & 2,160 & $\mathrm{P}$ & $\mathrm{U}$ & H. avenae \\
\hline $\mathrm{W}-2$ & Island City, OR & October 2008 & Wheat & 720 & $\mathrm{P}$ & $\mathrm{U}$ & H. avenae \\
\hline W-3 & Island City, OR & October 2008 & Wheat & 3,000 & $\mathrm{P}$ & $\mathrm{U}$ & H. avenae \\
\hline S-1 & Palouse, WA & October 2008 & Chickpea $^{\mathrm{d}}$ & 3,600 & $\mathrm{P}$ & $\mathrm{U}$ & H. avenae \\
\hline S-2 & Palouse, WA & October 2008 & Chickpea $^{\mathrm{d}}$ & 9,760 & $\mathrm{P}$ & $\mathrm{U}$ & H. avenae \\
\hline$S-3$ & Palouse, WA & October 2008 & Chickpea $^{\mathrm{d}}$ & 2,660 & $\mathrm{P}$ & $\mathrm{U}$ & H. avenae \\
\hline D-1 & St Anthony, ID & October 2008 & Potato $^{d}$ & 52,800 & $\mathrm{P}$ & $\mathrm{U}$ & H. avenae \\
\hline D-2 & St Anthony, ID & October 2008 & Potato $^{d}$ & 42,960 & $\mathrm{P}$ & $\mathrm{U}$ & H. avenae \\
\hline D-3 & St Anthony, ID & October 2008 & Potato $^{d}$ & 47,280 & $\mathrm{P}$ & $\mathrm{U}$ & H. avenae \\
\hline
\end{tabular}

${ }^{a}$ Density represents the total number of eggs and juveniles in $1 \mathrm{~kg}$ of soil, as reported by Western Laboratories (Parma, ID).

b P: tested by PCR-RFLP technique.

${ }^{c} \mathrm{U}$ : applied to analysis of underbridge structure; N/A: not available for analysis of underbridge.

${ }^{\mathrm{d}}$ Fields sampled after a broadleaf (nonhost) crop was planted to wheat before the crop that is shown in the table. 
Cloning and sequencing. The PCR fragments from three $H$. filipjevi populations (Fig. 1, grid site no. 23; Table 2, B-1 and RP6) were cloned and sequenced by the procedures as described by Yan et al. (40) to confirm the species identity. The bands subjected to cloning and sequence analysis were cut from a dried polyacrylamide gel and soaked in $2 \mu \mathrm{l}$ of $\mathrm{H}_{2} \mathrm{O}$ and then the solution was used as the DNA template for reamplification with the original primers. The reamplification product that generated a single band with the same size as the original band was selected for cloning into vector TOPO TA pCR2.1 (Invitrogen, Carlsbad, CA). Plasmid DNA from 10 single colonies derived from each cloning reaction was run in agarose gel to examine the size of the inserted fragment. Two or more clones with the expected insert size were sequenced using the ABI 377 sequencer (Applied Biosystems, Foster City, CA). The sequences obtained in this study were compared with those of $H$. filipjevi and other related cyst species from the GenBank database using the BLAST program. The new sequence of the ITS region of $H$. filipjevi from Oregon was submitted to GenBank with accession number GU079654.

Morphological examination. Differentiation of $H$. avenae and $H$. filipjevi was based on color of mature cysts, underbridge structure in the vulval cone, shape of semifenestra in the fenestra area, and development of bullae. To observe the underbridge and semifenestra, the posterior end of a cyst was excised under a stereomicroscope and an $\approx 100$-by-100- $\mu$ m section of the vulval cone with intact fenestral area was excised and prepared for observation (24). Microscopic observations were conducted with cysts from16 populations (Table 2). For each population, the cyst characters were evaluated on specimen numbers from 4 to 15 . Examinations were made with a compound Leica light microscope and photographs were taken with a Nikon camera (CoolPix 5700) attached to the microscope.

\section{RESULTS}

Nematode population density and distribution pattern. Grid soil sampling revealed that cyst nematodes were unevenly distributed in the winter wheat field where $H$. filipjevi was discovered near Imbler (Union County) OR. The cyst nematode distribution pattern is shown in Figure 1. Cyst nematodes were not detected in 35 of 50 sampling sites. The 15 sites infested with cyst nematodes included nine sites with population densities $<500$ juveniles/ $\mathrm{kg}$ of soil, three sites (nos. 14, 26, and 39) with $>500$ juveniles $/ \mathrm{kg}$ of soil, and two sites (nos. 10 and 42), with $>1,000$ juveniles $/ \mathrm{kg}$ of soil. One site (no. 23) contained high populations of $>2,000$ juveniles $/ \mathrm{kg}$ of soil. $H$. filipjevi was also detected in four other soil samples (B-1, C-1, R-P6, and R-26) at the same farm, as shown in Table 2.
Ten soil samples (Cu-1, Da-1, Wa-1, J-1, J-2, U-1, N-1, W-1, $\mathrm{W}-2$, and W-3) were collected from stunted patches of wheat at seven other farms near Union, Imbler, and Island City (Union County), OR (Table 2). These sampling sites were each within $10 \mathrm{~km}$ of the intensively sampled field near Imbler. Each of the 10 samples from the seven farms was found to be infested with cyst nematodes. Five samples had population densities $<500$ eggs and juveniles/kg of soil. Two samples (Wa-1 and W-2) contained $>500$ eggs and juveniles/kg of soil. Three samples (Da-1, W-1, and W-3) contained population densities of $>2,000$ eggs and juveniles $/ \mathrm{kg}$ of soil.

Six soil samples were collected during October 2008 from recently cultivated fields following a chickpea crop near Palouse, WA and following a potato crop near St. Anthony, ID (Table 2). Very high populations of cyst nematodes were detected in each of the three samples collected from each field. The three samples from Washington had population densities of 2,660 to 9,760 eggs and juveniles $/ \mathrm{kg}$ of soil. The three samples from Idaho had exceedingly high populations of $>40,000$ eggs and juveniles $/ \mathrm{kg}$ of soil.

Differentiation of $\boldsymbol{H}$. filipjevi and $\boldsymbol{H}$. avenae by PCR-RFLP. Genomic DNA was successfully extracted from juveniles or from cysts. DNA from all tested nematode populations and the control species produced a single fragment of $\approx 1,200 \mathrm{bp}$ when amplified with the primer pair $18 \mathrm{~S} / 26 \mathrm{~S}$. The amplified fragment contained the entire ITS region of rDNA, including ITS1, 5.8S rDNA gene, ITS2, and flanking areas of $18 \mathrm{~S}$ and $28 \mathrm{~S}$ genes. No PCR products were produced in the negative control without nematode DNA template.

RFLP analyses of the PCR products with six digestion enzymes (TaqI, HinfI, PstI, HaeIII, RsaI, and AluI) revealed that the banding patterns from B-1, C-1, R-P6, and R-26 (Table 2), and 12 grid sites (nos. 7, 10, 12, 14, 15, 17, 23, 26, 28, 34, 39, and 42), were the same as those of the previously verified $H$. filipjevi control samples but were different from the control samples of $H$. avenae. The banding patterns were also different than those of the control samples of $H$. latipons and $H$. schachtii when digested with Taq1, HaeIII, and RsaI, ruling out the possibility that the nematodes in these sites could be $H$. latipons or $H$. schachtii. Therefore, the cyst nematodes from these sites were suggested to be $H$. filipjevi. The RFLP banding patterns with TaqI are shown in Figure 2 for five of these sites. The banding patterns for the grid site no. 23 with five other enzymes were shown in Figure 3.

The other three grid sites (nos. 2, 6, and 33) infested with the cyst nematodes showed a type of banding pattern different from that of the control samples of $H$. filipjevi or $H$. avenae but exhibited the same restriction pattern as the mixture of the control samples of $H$. filipjevi and $H$. avenae when digested with TaqI,
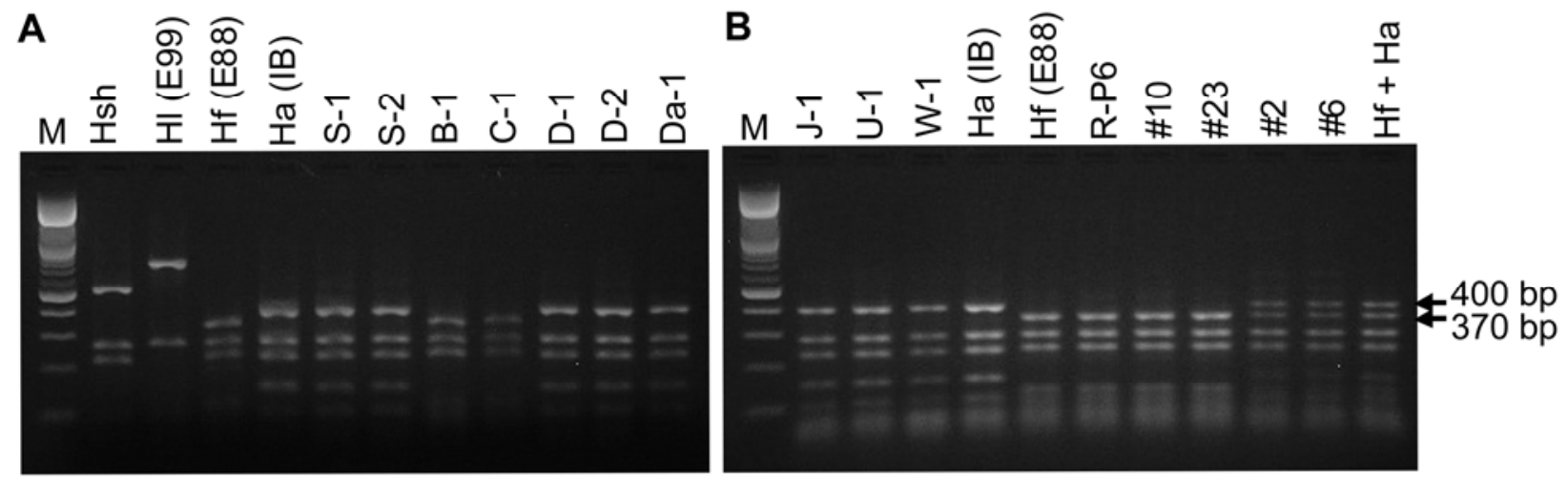

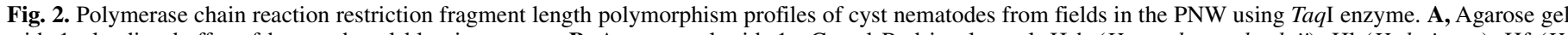

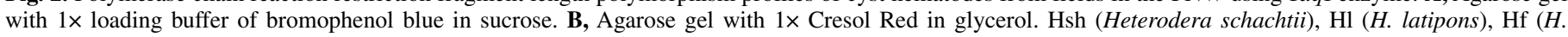

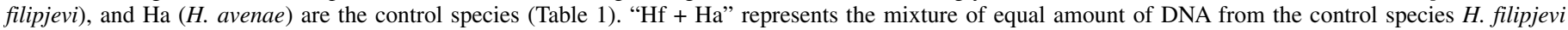

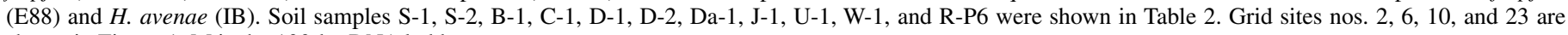
shown in Figure 1. M is the 100-bp DNA ladder. 
PstI, and HaeIII. The RFLP banding patterns for nos. 2 and 6 obtained with TaqI were shown in Figure 2. These samples not only had the specific marker (370 bp) produced by $\mathrm{H}$. filipjevi but also possessed the specific band (400 bp) produced by $H$. avenae, indicating that these sites contained a mixture of $H$. filipjevi and H. avenae (Fig. 2).

The amplified DNA from 16 soil samples (Cu-1, Da-1, Wa-1, J-1, J-2, U-1, N-1, W-1, W-2, W-3, S-1, S-2, S-3, D-1, D-2, and D3) (Table 2) in the surrounding area in Union County, OR and in the Washington and Idaho fields produced the same banding pattern as that of the $H$. avenae DNA standard and different from that of $H$. filipjevi. The banding patterns were also distinct from those of H. latipons and H. schachtii when digested with TaqI and HaeIII, suggesting that the species of cyst nematodes in these locations was $H$. avenae. The PCR-RFLP profiles for eight of these samples with $T a q \mathrm{I}$ were shown in Figure 2.

Intraspecific polymorphism was not observed within the $H$. filipjevi populations. The PCR-RFLP profiles for three $H$. filipjevi populations (B-1, R-P6, and grid site no. 42) were shown in Figure 4A with RsaI digestion and Figure 4B with AluI. Intraspecific variation was also not revealed within the $H$. filipjevi populations with $C f o$ I digestion. There was also no intraspecific polymorphism within the $H$. avenae populations in the PNW. However, intraspecific polymorphism was observed between the PNW H. avenae populations and the French population (IB). RsaI did not digest the PCR products of the PNW populations, showing only a single band $(1,200 \mathrm{bp})$, but did digest the PCR product of the French population, resulting in two additional bands (900 and $500 \mathrm{bp}$ ) (Fig. 4A). AluI digested the PCR fragments of the PNW populations, producing one very weak band (180 bp), and digested the PCR fragment of the French population, producing two bands (700 and $180 \mathrm{bp)} \mathrm{(Fig.} \mathrm{4B).}$

Species confirmation by cyst morphology. The cuticle of mature cysts were golden to light brown in color for $H$. filipjevi (Fig. 5A) and dark brown to black for H. avenae (Fig. 5B). Eggs of $H$. filipjevi were observed through the cyst cuticle more easily than eggs of $H$. avenae. The vulval cones in the $H$. filipjevi cysts had a well developed underbridge with bifurcated arms (Fig. 5A), whereas the $H$. avenae populations had no underbridge in the cyst vulval cones (Fig. 5B). The semifenestrae in H. filipjevi populations were horseshoe shaped (Fig. 5A), whereas the semifenestrae in $H$. avenae populations were generally oval (Fig. 5B). Bullae in
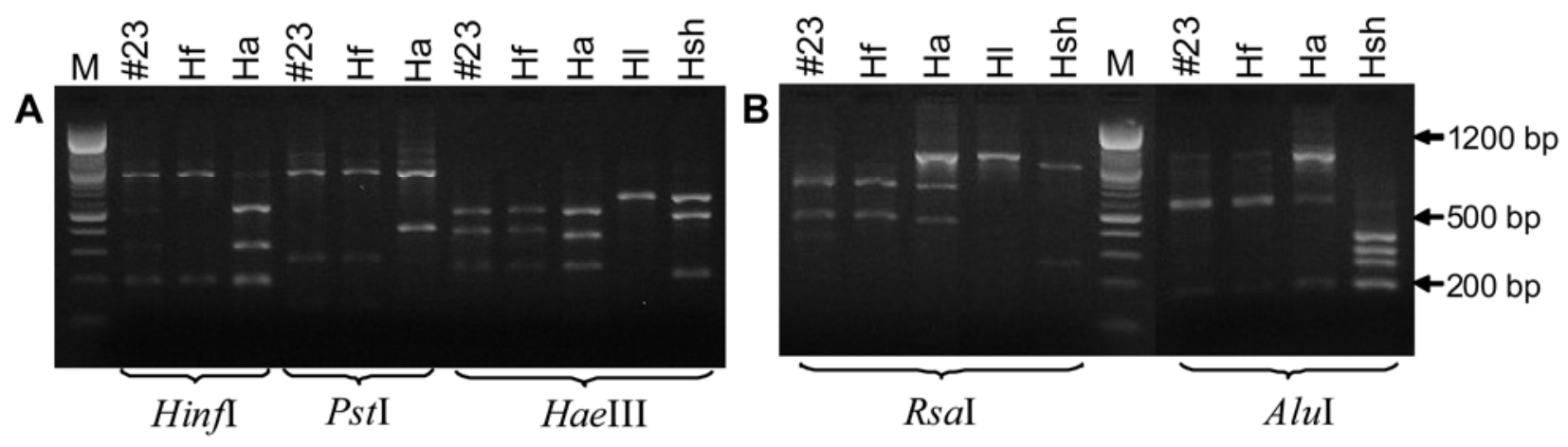

Fig. 3. Polymerase chain reaction restriction fragment length polymorphism patterns for the grid site no. 23 (Imbler, OR) digested with five restriction endonucleases. A, HinfI, PstI, and HaeIII. B, RsaI and AluI. Hf (H. filipjevi, E88), Ha (H. avenae, IB), HI (H. latipons, E99), and Hsh (H. schachtii, Hs) are the control species. M is the 100-bp DNA ladder.

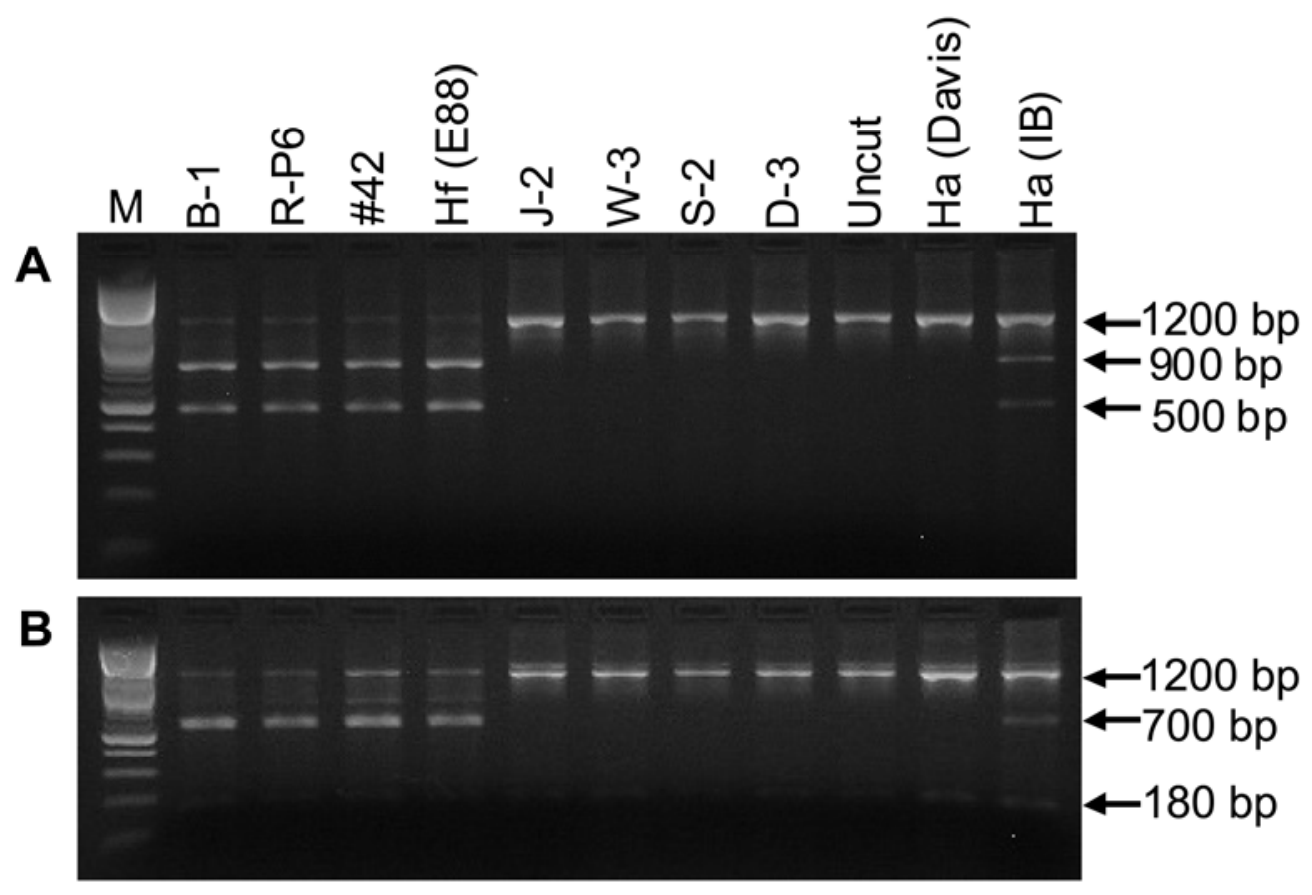

Fig. 4. Polymerase chain reaction-restriction fragment length polymorphism patterns of cyst nematodes in the Pacific Northwest fields. A, RsaI digestion. B, AluI digestion. Soil samples B-1, R-P6, J-2, W-3, S-2, and D-3 are shown in Table 2. Grid site no. 42 was in Figure 1. Hf $(H$. filipjevi) and Ha (H. avenae) are the control species. "Uncut" represents that the original PCR product was not digested with any restriction enzyme. M is the 100-bp DNA ladder. 
the $H$. filipjevi populations are small to medium in size and light to medium brown in color. In contrast, bullae in the $H$. avenae populations are well developed, numerous, and dark brown, often impeding the observation of the fenestral structure.

Confirmation of $\boldsymbol{H}$. filipjevi by ITS sequence. The sequencing data showed that the eight ITS sequences of rDNA from the three $H$. filipjevi populations were identical. The nucleotide blast analysis with known sequences in the GenBank showed that they were identical to the ITS sequences of three $H$. filipjevi isolates, one from Italy (AY347922) and two from Turkey (AY148398 and AY148397). Only one nucleotide was different than the ITS sequences of $H$. filipjevi isolates from the United Kingdom (AY148403), Tajikistan (AY148402), Russia (AY148401 and AF274399), Spain (AY148399), and Germany (AY148400), demonstrating $99 \%$ sequence similarity. The same single-nucleotide polymorphisms were present between the Imbler H. filipjevi $(\mathrm{C}$ in the 164th nucleotide) and the populations ( $\mathrm{T}$ in the corresponding position) from the United Kingdom, Tajikistan, Russia, and Germany. However, a different single nucleotide polymorphism was present between the populations from Imbler (A in the 916th nucleotide) and Spain ( $\mathrm{G}$ in the corresponding position). At least 22 nucleotides were different than some other species in the $H$. avenae group, including 73 isolates of $H$. avenae, 1 isolate of $H$. arenaria, 4 isolates of $H$. ustinovi, 4 isolates of $H$. australis, 5 isolates of $H$. pratensis, 2 isolates of $H$. mani, and 3 isolates of $H$. aucklandica, demonstrating 4 to $5 \%$ sequence divergence. Sequence dissimilarity for the Imbler $H$. filipjevi with three isolates of $H$. bifenestra, five isolates of $H$. hordecalis, and three isolates of $H$. latipons was 9 to $13 \%$.

\section{DISCUSSION}

PCR-RFLP tests with each of six endonucleases (TaqI, HinfI, PstI, HaeIII, RsaI. and AluI) allowed for rapid discrimination of $H$. filipjevi and $H$. avenae cysts extracted from PNW wheat fields. $H$. filipjevi and $H$. avenae were readily distinguished from $H$. latipons (another economically important cyst nematode on wheat) and $H$. schachtii (a widely distributed beet cyst nematode in Idaho and Oregon) with two of the endonucleases. Furthermore, ITS sequence data of $H$. filipjevi and the key morphological difference (H. filipjevi with a distinct underbridge and $H$. avenae without an underbridge in the cyst vulval cone) were obtained to confirm the accuracy of the species identification determined by PCR-RFLP. Generally, only one species in the H. avenae group is identified in most regions but mixtures of species can also occur within individual fields $(1,23)$. Our tests revealed that $H$. filipjevi was the only Heterodera sp. detected at most of the infested sites in the field that was grid sampled and in some other fields at the same farm. Mixtures of $H$. avenae and $H$. filipjevi were also detected at several other grid sites.

The strategy we found to be most effective for identifying mixed species included thoroughly mixing the soil samples, picking 20 juveniles randomly from the nematode extract for use in each DNA extraction, making three separate DNA extractions and PCR amplifications for each sample, using the three digestion enzymes TaqI, PstI, and HaeIII for each analysis, and using a mixture of the two control species as a standard. H. filipjevi was detected in several fields near Imbler, supporting the first report of this species in Oregon $(29,42)$. Grid soil sampling showed that CCNs were unevenly distributed across the field. Uneven distributions of nematodes in fields are common for many plantparasitic nematode genera and species $(21,43)$.

The cyst nematodes in soils collected from most areas of Union County, OR and two locations in Washington and Idaho were identified as $H$. avenae using the PCR-RFLP technique. Heterodera cysts extracted from another field in southern Idaho were determined to be $H$. schachtii (unreported data). To date, three reports have applied biochemical and molecular procedures to
PNW populations of $H$. avenae. Ferris et al. (4) reported that one isolate from Oregon and one from Idaho differed on the basis of two-dimensional polyacrylamide gel electrophoresis protein patterns but that both isolates showed protein patterns consistent with the species $H$. avenae. Subbotin et al. (30) compared the rDNA ITS sequence data of these two $H$. avenae isolates with consensus sequence data of $H$. avenae from other regions and stated, without presentation of data, that the two North American isolates clustered with European $H$. avenae. Populations from three farms in Union County, OR were also reported as $H$. avenae based on unpublished results from commercial but proprietary DNA tests provided by the South Australian Research and Development Institute (SARDI), Adelaide, Australia $(18,19)$. However, the Australian test was designed to detect and quantify populations of $H$. avenae in that country and is now known to be unable to distinguish between $H$. avenae and $H$. filipjevi (A. C. McKay, SARDI, Adelaide, Australia, personal communication). Smiley et al. (29) applied the PCR-RFLP procedure to assure that they detected homogeneous populations of $H$. avenae; however, during that experimentation, they found that cysts from a field near Imbler consistently showed restriction patterns distinctly different from that of an $H$. avenae DNA standard and the same as that of an $H$. filipjevi standard, using four enzymes. Further morphological evidence confirmed that the Imbler cysts were $H$. filipjevi and thereby resulted in the first detection of $H$. filipjevi in North America.

All six restriction enzymes (TaqI, HinfI, PstI, HaeIII, RsaI, and AluI) allowed for distinguishing between $H$. filipjevi and $H$. avenae and two enzymes (TaqI and HaeIII) separated $H$. filipjevi and $H$. avenae from $H$. latipons and $H$. schachtii. Bekal et al. (2) reported that digestion with TaqI clearly differentiated $H$. filipjevi, $H$. avenae, and $H$. latipons, and Subbotin et al. (33) stated that it clearly differentiated populations of $H$. filipjevi from other species of the $H$. avenae group. Bekal et al. (2) reported that digestion with PstI clearly separated $H$. filipjevi from $H$. avenae and Subbotin et al. (33) reported that it clearly distinguished $H$. filipjevi from other species of the $H$. avenae group. HinfI was reported to distinguish $H$. filipjevi from $H$. avenae $(1,33)$. HaeIII was reported to differentiate $H$. filipjevi, $H$. avenae, $H$. latipons, and $H$. schachtii $(1,23)$. RsaI and AluI digestions permitted differentiation of $H$. filipjevi from the two control isolates of $H$. avenae in our tests. However, Bekal et al. (2) and Rivoal et al. (23) reported that $H$. filipjevi and $H$. avenae populations produced the same RFLP pattern when digested with RsaI or AluI, which may be due to different genetic population types used in their study. Compared with the published results $(23,30)$, combinations of TaqI, PstI, HinfI, HaeIII, and RsaI were able to differentiate $H$. filipjevi from $H$. arenaria, $H$. hordecalis, $H$. mani, and $H$. pratensis. Combinations of HinfI, HaeIII, and RsaI differentiated $H$. avenae from $H$. hordecalis, $H$. mani, and $H$. pratensis.

Intraspecific polymorphism was not observed within $H$. filipjevi populations extracted from soils near Imbler and between $H$. filipjevi populations from Oregon and France. Similarly, Subbotin et al. (30) reported that they did not observe intraspecific polymorphism within two populations of $H$. filipjevi from Turkey, within two populations from Iran, within two from Russia, between populations of Turkey and Spain, and between populations from Iran, Russia, the United Kingdom, Tadzhikistan, and Germany. However, they observed intraspecific polymorphism between $H$. filipjevi populations from Turkey and Spain and from Iran, Russia, the United Kingdom, Tadzhikistan, and Germany by $C f o$ I. Abidou et al. (1) reported that no intraspecific polymorphism was observed within $H$. filipjevi populations from Turkey and India using four endonucleases (HaeIII, HinfI, ItaI, and PstI).

Intraspecific variation was not observed within populations of $H$. avenae from Idaho, Oregon, and Washington. However, intraspecific variation was observed between $H$. avenae populations occurring in the PNW and France. Subbotin et al. (33) 
revealed that three genetic types of ITS region were identified for $H$. avenae populations using $R s a \mathrm{I}$ and $A l u \mathrm{I}$. Type A for most European populations showed only one unrestricted band; type B for an Indian population showed only additional bands; and their combination (type A+B) for three French populations had one unrestricted band with additional bands. Therefore, compared with the results obtained by Subbotin et al. (33), type A was suggested for the PNW populations and type A+B was confirmed for the French population (IB). The ITS heterogeneity demonstrated here might reflect the influence of evolutionary interactions between populations (33). The difference in the size of restriction fragments between this study and Subbotin et al. (33) for the French population was due to the amplification of a longer part of the rDNA, 1,200 bp instead of 1,060 bp, amplified with a different primer pair, AB 28/TW 81, used by Subbotin et al. (33). Subbotin et al. (33) showed that digestion with $R s a \mathrm{I}$ and $A l u \mathrm{I}$ allowed separation of $H$. filipjevi from the European $H$. avenae populations (type A) and the three French populations (type A+B) but did not separate $H$. filipjevi from the Indian population (type B).

$H$. filipjevi is closely related to $H$. avenae in the $H$. avenae group complex and morphometric measurements on cysts and second-stage juveniles for these two species are either overlapping or have very small differences $(8,30)$. The key morphological features of cyst color, underbridge in the vulval cone, semifenestra shape, and development of bullae are used to distinguish $H$. filipjevi and $H$. avenae. Madzhidov (13) described a cyst-forming nematode previously identified as $H$. avenae near Dushanbe, Tadzhikistan as the new species of $H$. filipjevi based on the presence of a characteristic underbridge in the cyst vulval cones and other differences in juveniles and cysts from other species. The characteristic difference between $H$. avenae and $H$. filipjevi was the presence of a distinct underbridge in the cyst vulval cone of $H$. filipjevi as opposed to the absence of an under-

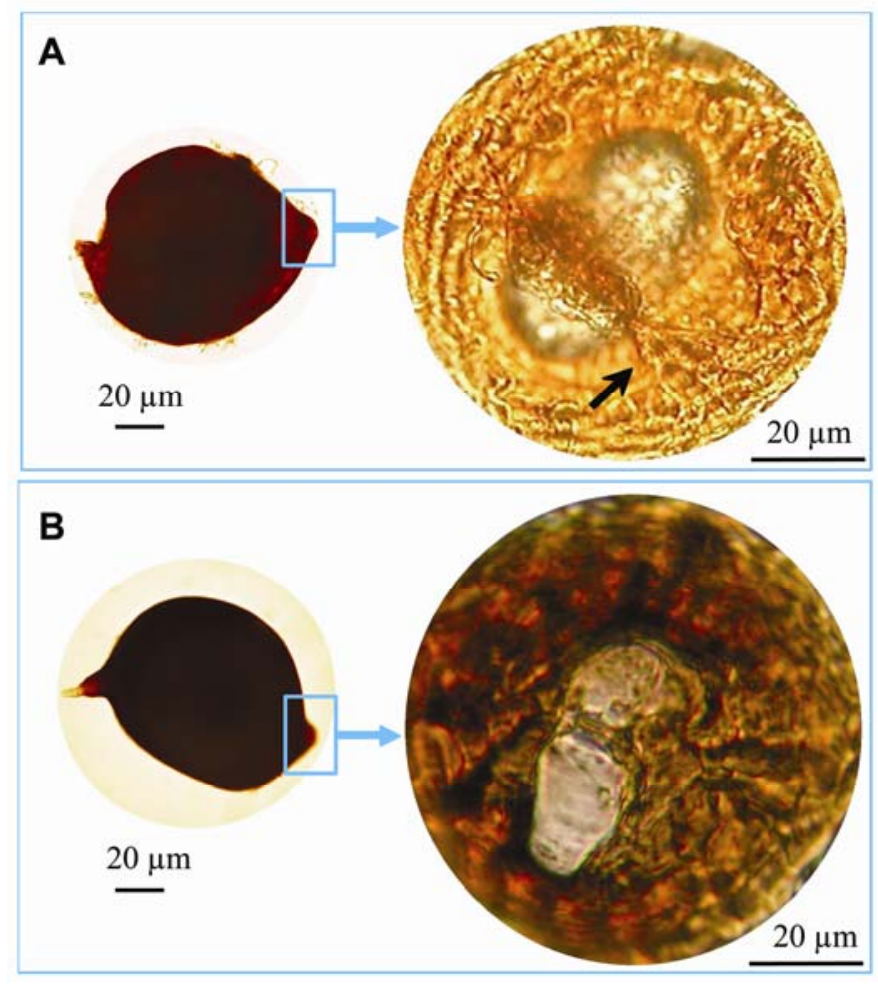

Fig. 5. Microscopic views of cysts and vulval cones of Heterodera spp. A, Heterodera filipjevi: a whole cyst, light brown in color, and a vulval cone showing the horseshoe-shaped semifenestra and the distinct underbridge (black arrow). B, H. avenae: a whole cyst, dark brown in color, and a vulval cone showing the oval semifenestra and the absence of an underbridge. bridge in that of $H$. avenae $(1,30,39)$ (Roger Rivoal, INRA, Rennes, France, personal communication). Cyst color, semifenestra shape, and bulla development were found to be different between $H$. avenae and $H$. filipjevi $(1,9)$ but each of these characters would be difficult to apply with certainty as a diagnostic criterion for purposes of routine soil sampling. In our experiment, the differentiation of specimens based on the presence or absence of an underbridge was successful at low magnification with a regular microscope, even for the sample (grid site no. 2) with mixed species. However, preparation of the tiny pieces of vulval cones was tedious and time consuming and was restricted by numbers and quality of cysts available from soil extractions. Some soil samples with low population densities shown in Table 2 and Figure 1 were not applied to analysis of underbridge structure because of limited cyst material or poor quality of cysts for microscopic dissection. The PCR-RFLP analysis provided a quick way for determining the species identity for these samples using DNA of juveniles extracted directly from soils.

H. filipjevi differed from $H$. arenaria, H. hordecalis, H. mani, $H$. pratensis, and $H$. bifenestra by the typical underbridge with bifurcated arms in the vulval cone $(8,30)$. H. avenae differed from $H$. hordecalis by the absence of an underbridge and differed from $H$. bifenestra by the presence of well-developed bullae surrounding cyst vulval cones (8). Second-stage juveniles of $H$. arenaria can be easily distinguished from juveniles of $H$. avenae by their greater length (33). In our research, juveniles from $H$. avenae cysts in Oregon averaged $561 \mu \mathrm{m}$, closely matching the averages described for this species and outside the averages described for $H$. arenaria by Handoo (8) and Subbotin et al. (30). Additionally, $H$. avenae was differentiated from $H$. mani and $H$. pratensis by different PCR-RFLP restriction patterns digested with HinfI $(23,30)$. Therefore, combinations of molecular tests and morphological examinations are able to discriminate $H$. filipjevi and $H$. avenae from other closely related species of the $H$. avenae group.

High populations of $H$. avenae and $H$. filipjevi were found to be present in some sampled fields. Populations $>200$ juveniles $/ \mathrm{kg}$ of soil are likely to reduce wheat yield, particularly when combined with other stress factors such as diminishing supply of water or plant nutrition late in the growing season. The three samples from Idaho had exceedingly high populations (>40,000 eggs and juveniles $/ \mathrm{kg}$ of soil) of $H$. avenae that were at least 20 times higher than that required to cause significant yield loss in wheat. Each of the growers who allowed us to collect soil from their fields was unaware that a high population of cyst nematodes was a possible reason for the patchiness and reduced wheat yields they were experiencing.

Application of the molecular tests described here, and particularly of the combination of molecular and morphological examinations, are likely to facilitate a greater use of routine nematode testing of PNW dryland field crops regions, nearly all of which have never been subjected to a systematic survey for the presence of cyst nematodes. Sampling protocols used in this study were not designed to examine the overall distribution of $H$. filipjevi. In view of widespread movement of infested soil in the area now known to be infested by both $H$. filipjevi and $H$. avenae $(25,26$, $28,29,41,42)$, it is possible that a systematic survey could reveal a wider geographic distribution as well as the occurrence of low populations of $H$. filipjevi in fields where only $H$. avenae has been detected previously and in this experiment.

The use of resistant cultivars offers the most effective and economic option to control damage from CCNs. The Crel gene carried by a hexaploid wheat line that is not adapted to the PNW climate was shown to be capable of preventing reproduction of $H$. avenae populations in eastern and western Oregon (25). The Crel gene has been incorporated into PNW-adapted wheat cultivars and this gene is equally effective against populations of both $H$. avenae and $H$. filipjevi in Norway and Turkey. Effective resistance 
genes against $H$. filipjevi in Oregon are being identified using the International Test Assortment composed of 23 barley, wheat, and oat lines containing defined genes for resistance to members of the $H$. avenae group, including $H$. filipjevi. The best possible outcome would be a demonstration that the Crel gene is as effective against $H$. filipjevi as it is against $H$. avenae in Oregon. However, populations of $H$. filipjevi occurring in India and Sweden are not controlled by the Crel gene. If the Oregon population of $\mathrm{H}$. filipjevi is not controlled by Crel, another gene identified from our tests will be introduced into the PNW wheat cultivars already carrying the $\mathrm{Cr} / \mathrm{l}$ gene, pyramiding these sources of resistance to both nematodes. This will be important in fields where $H$. filipjevi already coexists with $H$. avenae, and in $H$. avenae-infested fields likely to also become infested with $H$. filipjevi due to the efficient spread of these species in soil transferred by wind, water, and soil that contaminates agricultural products, animals, equipment, and humans (dusty or muddy boots). When cultivars resistant to $H$. avenae and $H$. filipjevi become available, the small-grain producers in areas of at least seven states where CCNs are reported (25) will be able to achieve a higher economic efficiency for their farm enterprises.

\section{ACKNOWLEDGMENTS}

This research was supported by a subcontract between Oregon State University and the United States Department of Agriculture-Agricultural Research Service (SCA 58-5348-9-100, "Control of Root Diseases of Wheat and Barley"). We thank R. Rivoal and E. Grenier (INRA, Rennes, France) for providing DNA standards of control specimens of Heterodera spp.; A. Thompson, J. Gourlie, and H. Yan for soil sampling and cyst nematode extraction; owners of fields we sampled and scientists who assisted with collection of samples in Washington (T. Paulitz) and Idaho (J. Windes) for their cooperation; and Western Laboratories (Parma, Idaho) for providing cyst nematode diagnostic services.

\section{LITERATURE CITED}

1. Abidou, H., Valette, S., Gauthier, J. P., Rivoal, R., El-Ahmed, A., and Yahyaoui, A. 2005. Molecular polymorphism and morphometrics of species of the Heterodera avenae group in Syria and Turkey. J. Nematol. 37:146-154.

2. Bekal, S., Gauthier, J. P., and Rivoal, R. 1997. Genetic diversity among a complex of cereal cyst nematodes inferred from RFLP analysis of the ribosomal internal transcribed spacer region. Genome 40:479-486.

3. Chen, W. 1992. Restriction fragment length polymorphism in enzymatically amplified ribosomal DNAs of three heterothallic Pythium species. Phytopathology 82:1467-1472.

4. Ferris, V. R., Ferris, J. M., Faghihi, J., and Ireholm, A. 1994. Comparisons of isolates of Heterodera avenae using 2-D PAGE protein patterns and ribosomal DNA. J. Nematol. 26:144-151.

5. Hafez, S. L., and Golden, A. M. 1984. First report of oat cyst nematode in eastern Washington. (Abstr.) Plant Dis. 68:351.

6. Hafez, S. L., and Golden, A. M. 1985. First report of oat cyst nematode (Heterodera avenae) on barley in Idaho. (Abstr.) Plant Dis. 69:360.

7. Hafez, S. L., Golden, A. M., Rashid, F., and Handoo, Z. 1992. Plantparasitic nematodes associated with crops in Idaho and eastern Oregon. Nematropica 22:193-204.

8. Handoo, Z. A. 2002. A key and compendium to species of the Heterodera avenae Group (Nematoda: Heteroderidae). J. Nematol. 34:250-262.

9. Holgado, R., Andersson, S., Rowe J. A., and Magnusson, C. 2004. First record of Heterodera filipjevi in Norway. Nematol. Mediterr. 32:205-211.

10. Ibrahim, S. K., Perry, R. N., Burrows, P. R., and Hooper, D. J. 1995. Differentiation of species and populations of Aphelenchoides and of Ditylenchus angustus using a fragment of ribosomal DNA. J. Nematol. 26:412-421.

11. Jensen, H. J., Eshtiaghi, H., Koepsell, P. A., and Goetze, N. 1975. The oat cyst nematode, Heterodera avenae, occurs on oats in Oregon. Plant Dis. Rep. 59:1-3.

12. Madani, M., Vovlas, N., Castillo, P., Subbotin, S. A., and Moens, M. 2004. Molecular characterization of cyst nematode species (Heterodera spp.) from the Mediterranean Basin using RFLPs and sequences of ITSrDNA. J. Phytopathol. 152:229-234.

13. Madzhidov, A. R. 1981. Bidera filipjevi n. sp. (Heteroderina: Tylenchida) in Tadzhikistan. Izv. Akad. Nauk Tadzh. SSR Otd. Biol. Nauk 2:40-44.
14. McDonald, A. H., and Nicol, J. M. 2005. Nematode parasites of cereals. Pages 131-191 in: Plant Parasitic Nematodes in Subtropical and Tropical Agriculture. M. Luc, R.A. Sikora, and J. Bridge, eds. CAB International, Wallingford, UK.

15. Mokabli, A., Valette, S., Gauthier, J.-P., and Rivoal, R. 2002. Variation in virulence of cereal cyst nematode populations from North Africa and Asia. Nematology 4:521-525.

16. Nicol, J., Rivoal, R., Taylor, S., and Zaharieva, M. 2003. Global importance of cyst (Heterodera spp.) and lesion nematodes (Pratylenchus spp.) on cereals: Distribution, yield loss, use of host resistance and integration of molecular tools. Nematol. Monogr. Perspect. 2:1-19.

17. Nicol, J. M. 2002. Important nematode pests of cereals. Pages 345-366 in: Bread Wheat: Improvement and Production. B. C. Curtis, S. Rajaram, and Gómez Macpherson, eds. United Nations Food Agric. Organ. Plant Prod. Prot. Ser. Rome.

18. Ophel-Keller, K., Hartley, D., McKay, A., Herdina, and Curran, J. 2008. Development of a routine DNA-based testing service for soil-borne diseases in Australia. Australas. Plant Pathol. 37:243-253.

19. Ophel-Keller, K., and McKay, A. 2001. Root disease testing service: Delivery and commercialization. Pages 17-18 in: Proc. 2nd Australas. Soilborne Dis. Symp. I. J. Porter, ed. Victoria Dep. Nat. Res. Environ. Australia.

20. Orui, Y. 1997. Discrimination of Globodera rostochiensis and four Heterodera species (Nematoda: Heteroderidae) by PCR-RFLP analysis. Jpn. J. Nematol. 27:67-75

21. Qiu, J. J., Westerdahl, B. B., Anderson, C., and Williamson, V. 2006. Sensitive PCR detection of Meloidogyne arenaria, M. incognita, and $M$. javanica extracted from soil. J. Nematol. 38:434-441.

22. Rivoal, R., and Cook, R. 1993. Nematode pests of cereals. Pages 259-303 in: Plant Parasitic Nematodes in Temperate Agriculture. K. Evans, D. L. Trudgill, and J. M. Webster, eds. CAB International, Wallingford, UK.

23. Rivoal, R., Valette, S., Bekal, S., Gauthier, J.-P., and Yahyaoui, A. 2003. Genetic and phenotypic diversity in the graminaceous cyst nematode complex, inferred from PCR-RFLP of ribosomal DNA and morphometric analysis. Eur. J. Plant Pathol. 109:227-241.

24. Shurtleff, M. C., and Averre, C. W., III. 2000. Diagnosing Plant Diseases Caused by Nematodes. The American Phytopathological Society, St. Paul, MN.

25. Smiley, R. W. 2009. Occurrence, distribution and control of Heterodera avenae and $H$. filipjevi in the western USA. Pages 35-40 in: Proc. 1st Int. Cereal Cyst Nematodes Initiative. I. T. Riley, J. M. Nicol, and A. A. Dababat, eds. CIMMYT, Ankara, Turkey.

26. Smiley, R. W., Ingham, R. E., Uddin, W., and Cook, G. H. 1994. Crop sequences for managing cereal cyst nematode and fungal pathogens of winter wheat. Plant Dis. 78:1142-1149.

27. Smiley, R. W., and Nicol, J. M. 2009. Nematodes which challenge global wheat production. Pages 171-187 in: Wheat Science and Trade. B. F. Carver, ed. Wiley-Blackwell Publishers, Ames, IA.

28. Smiley, R. W., Whittaker, R. G., Gourlie, J. A., Easley, S. A., and Ingham, R. E. 2005. Plant-parasitic nematodes associated with reduced wheat yield in Oregon: Heterodera avenae. J. Nematol. 37:297-307.

29. Smiley, R. W., Yan, G. P., and Handoo, Z. A. 2008. First record of the cyst nematode Heterodera filipjevi on wheat in Oregon. Plant Dis. 92:1136.

30. Subbotin, S. A., Sturhan, D., Rumpenhorst, H. J., and Moens, M. 2003. Molecular and morphological characterisation of the Heterodera avenae species complex (Tylenchida: Heteroderidae). Nematology 5:515-538.

31. Subbotin, S. A., Vierstraete, A., De Ley, P., Rowe, J., Waeyenberge, L., Moens, M., and Vanfleteren, J. R. 2001. Phylogenetic relationships within the cyst-forming nematodes (Nematoda, Heteroderidae) based on analysis of sequences from the ITS regions of ribosomal DNA. Mol. Phylogenet. Evol. 21:1-16.

32. Subbotin, S. A., Waeyenberge, L., and Moens, M. 2000. Identification of cyst forming nematodes of the genus Heterodera (Nematoda: Heteroderidae) based on the ribosomal DNA-RFLPs. Nematology 2:153-164.

33. Subbotin, S. A., Waeyenberge, L., Molokanova, I. A., and Moens, M. 1999. Identification of Heterodera avenae group species by morphometrics and rDNA-RFLPs. Nematology 1:195-207.

34. Szalanski, A., Sui, D. D., Harris, T. S., and Powers, T. O. 1997. Identification of cyst nematodes of agronomic and regulatory concern with PCR-RFLP of ITS1. J. Nematol. 29:255-267.

35. Tanha Maafi, Z., Subbotin, S. A., and Moens, M. 2003. Molecular identification of cyst-forming nematodes (Heteroderidae) from Iran and a phylogeny based on ITS-rDNA sequences. Nematology 5:99-111.

36. Vrain, T. C., Wakarchuk, D. A., Lévesque, A. C., and Hamilton, R. I. 1992. Intraspecific rDNA restriction fragment length polymorphism in the Xiphinema americanum group. Fundam. Appl. Nematol. 15:563-573.

37. Waeyenberge, L., Ryss, A., Moens, M., Pinochet, J., and Vrain, T.C. 2000. Molecular characterization of 18 Pratylenchus species using rDNA restriction fragment length polymorphism. Nematology 2:135-142.

38. Whitehead, A. G., and Hemming, J. R. 1965. A comparison of some 
quantitative methods of extracting small vermiform nematodes from soil. Ann. Appl. Biol. 55:25-38.

39. Wouts, W. M., Schoemaker, A., Sturhan, D., and Burrows, P. R. 1995. Heterodera spinicauda sp. n. (Nematoda: Heteroderidae) from mud flats in the Netherlands, with a key to the species of the $H$. avenae group. Nematology 41:575-583.

40. Yan, G. P., Chen, X. M., Line, R. F., and Wellings, C. R. 2003. Resistance gene-analog polymorphism markers co-segregating with the $\mathrm{Yr} 5$ gene for resistance to wheat stripe rust. Theor. Appl. Genet. 106:636-643.

41. Yan, G. P., and Smiley, R. W. 2008. First detection of the cereal cyst nematode Heterodera filipjevi in North America. (Abstr.) Phytopathology 98:S176.

42. Yan, G. P., and Smiley, R. W. 2009. Discovery of Heterodera filipjevi on wheat in the USA. Pages 94-99 in: Proc. 1st Int. Cereal Cyst Nematodes Initiative. I. T. Riley, J. M. Nicol, and A. A. Dababat, eds. CIMMYT, Ankara, Turkey.

43. Yan, G. P., Smiley, R. W., Okubara, P. A., Skantar, A., Easley, S. A., Sheedy, J. G., and Thompson, A. L. 2008. Detection and discrimination of Pratylenchus neglectus and P. thornei in DNA extracts from soil. Plant Dis. 92:1480-1487. 